Ivanova T. (2021): Advanced receptions in the methodology of extraction total and viral nucleic acids from basidiomycetes. Agriculture and Forestry, 67 (1): 83-90

DOI: 10.17707/AgricultForest.67.1.07

Tetiana IVANOVA

\title{
ADVANCED RECEPTIONS IN THE METHODOLOGY OF EXTRACTION TOTAL AND VIRAL NUCLEIC ACIDS FROM BASIDIOMYCETES
}

\begin{abstract}
SUMMARY
Existing governmental programs aimed to increase mushrooms production and significant market demand for mushrooms contributed to the expansion of such production. Meanwhile, until now practically don't exist highly precised molecular diagnostics for the detection and identification of mycoviruses that strike the Basidiomycetes in Ukraine. The purpose and objectives are to study modern methods of extraction of total RNA from Basidiomycetes and their modifications and improvements as well as the molecular biological systems test for the identification of Basidiomycetes mycoviruses. This research was carried out by way of with follow techniques: molecular biological (the method of extraction of total RNA, dsDNA, precipitation, amplification); biotechnological (obtaining and subcultivation of samples of mycelium in vitro using electrophoresis in agarose and polyacrylamide gels (PAGE); microbiological (obtaining pure mushroom culture, determining the hydrogen index $(\mathrm{pH})$ of the nutrient medium), mycological (a measurement of growth), virology, microscopy. Interpretation statistics data was carried out with the help of computer software. Screening of mushroom's samples has been performed in the Kyiv region. The virus infection and prevalence of viral diseases of mushrooms have been researched. The modification of method of extraction total and viral nucleic acids from Basidiomycetes has been proposed. It is based on the acceleration of the stage of cellulose-chromatographic purification of nucleic acids and fractionation of dsRNA. It is proposed to propagate the first stage of low-speed centrifugation at high speeds from $6000 \mathrm{~g}$ to $8000 \mathrm{~g}$. Such centrifugation is performed according to the method after the first phenol isolation of total nucleic acids. In the future it is proposed to perform only one instead of two stages of the cellulose gradient for double-stranded ribonucleic acids of the test sample. As a result of the modification a larger number of nucleic acids has been received. An alternative step was introduced for reducing the loss of RNA from natural abrasives by increase the weight of samples to $10 \mathrm{~g}, 30 \mathrm{ml}$ STE buffer for initial washing, 50 $\%$ of the phenol's volume, $17 \mathrm{ml}$ of chloroform, and $2 \mathrm{ml}$ of isoamyl alcohol.

\footnotetext{
${ }^{1}$ Tetiana Ivanova, (tivanova1@ukr.net) Faculty of Plant Protection Biotechnology and Ecology, National University of Life and Environmental Science of Ukraine, UKRAINE

Paper presented at the $11^{\text {th }}$ International Scientific Agricultural Symposium "AGROSYM 2020".

Notes: The author declares that she has no conflicts of interest. Authorship Form signed online.

Recieved:11/10/2020

Accepted:20/12/2020
} 
Under conditions of allocation double-stranded viral RNA appears to confirm the effectiveness of the proposed method of diagnosis and identification of viral RNA in Basidiomycetes.

Keywords: Extraction, Basidiomycetes, viral disease, methodology, total and double-stranded RNA, diagnostics

\section{INTRODUCTION}

Mushrooms are well known for their nutritional good values worldwide. Interest in them is at the peak because immunity and cellular protection are important issues for health- conscious consumers. Generally, mushrooms belong to Basidiomycetes. It included mushroom species with a diversity of metabolites of nutraceutical and therapeutic significance. They have been reported that it is the most valuable ones for humans (Pereyma, 2017; Patyka V.P. et al., 2019; Vanina and Ivanova, 2019)

International Meeting of the Conservation and Utilization of Genetic Resources of Mushrooms proposed the collection and conservation of the wild useful mushroom germplasm.

The main prerequisites for high yields of mushrooms are introduction and using of high-quality spawn without pathogens and disease resistant (Grogan and Tomprefa, 2002; Grogan et al., 2003; Maffettone, 2007; Ivanova, 2017).

The mushroom (Agaricus bisporus (J. Lge) Imbach) is the most widely cultivated mushroom culture in the world. It accounts for 35-45\% of the total production of mushrooms. In recent years, viruses are made deleterious diseases for mushroom cultures. (Grogan et al., 2003; Maffettone, 2007; Elibuyuk,and Bostan, 2010;Ivanova, 2015, 2018, 2019, 2020, Klyachenko and Prysiazhnuk 2019).

Diagnosis has made considerable sense in assessing the source and breeding material for resistance to viral diseases. Several methods are used for diagnostic and identification of mycoviruses. The most relevant and accurate are molecular-biological and biochemical methods for diagnosing pathogens which affect Basidiomycetes.

Agaricus bisporus has over ten described pathogenic viruses. Heretofore practically do not exist highly precised molecular diagnostics for the detection and identification of mycoviruses that strike the Basidiomycetes in Ukraine.

The most dangerous among them is La France (LFIV or LIV). This isometric virion by the size of $35 \mathrm{~nm}$. The virus has been the subject of extensive epidemiological studies and fight, so now La France disease is rare (Grogan, and Tomprefa, 2002; Grogan et al., 2003). The British scientists reported a reduction in yield mushrooms, which causes failure to install. The symptoms were absent, but the mycelium was almost with no signs of growth fruiting bodies. Some farms were affected by a similar ethicology increased. Some symptoms of the La France disease, but the diagnostic tests showed negative results for the spherical virus. Recently, the disease was associated with the presence of double-stranded RNA new elements (Maffettone, 2007). However, dsRNA different from 
previously described dsRNAs elements characteristic of the La France disease. It was suggested that the disease-induced previously undescribed virus with characteristic dsRNA genome. It was called "virus X", and then Mushroom Virus $\mathrm{X}(\mathrm{MVX})$. It is proved that the viral disease fruiting bodies of mushrooms changed they're morphologically losing its taste, have reduced shelf life, and are often dangerous to use.

As a result, increasing environmental problems are leading to a decrease in the resistance of mushroom grown in industrial conditions to abiotic and biotic factors. Therefore, recently the development of the mushroom industry has focused on studying the ways of transmission of fungal, bacterial, and viral diseases and creating a methodology which capable of responding quickly to stress and further regulation (Grogan et al., 2003; Maffettone, 2007).

The purpose of the research is to adapt and improve the method of separation, purification, and identification of viral total and double-stranded RNA from Basidiomycetes for their diagnosis and identification by highly pathogenic mycoviruses.

\section{MATERIAL AND METHODS}

The experimental part of the work was performed from 2011 to 2017 on the basis in the Problem Laboratory of Phytovirology and Biotechnology of the National University of Life and EnvironmentalSciences of Ukraine (Kyiv, Ukraine). Some researches were carried out in the research Department of molecular diagnostic researches of the Ukrainian Laboratory of Quality and Safety of Agroindustrial Complex Products (Kyiv, Ukraine), in the Laboratory of mycelium production of Agro-Industrial Complex (Kyiv, Ukraine), at the private mushroom enterprises of Kyiv region.

\section{Screening of viral diseases of mushrooms}

The samples with and without specific symptoms were used to study viral pathogens of mushrooms Table 1 (Ivanova, 2019.

Table 1. Detection of viral diseases of mushrooms in the Kyiv region

\begin{tabular}{|l|l|c|c|}
\hline $\begin{array}{l}\text { Research area (spread) of viral } \\
\text { diseases }\end{array}$ & $\begin{array}{l}\text { External symptoms of fruiting } \\
\text { bodies }\end{array}$ & $\begin{array}{l}\text { Detection of viruses by } \\
\text { dsRNA isolation }\end{array}$ & $\begin{array}{l}\text { Lesions, } \\
\% \pm, \\
\mathrm{M} \pm\end{array}$ \\
\hline $\begin{array}{l}\text { Kyiv region, Vasylkiv district, } \\
\text { Private enterprise }\end{array}$ & Dark brown spots, watery legs & + & $8.5 \pm 0.5$ \\
\hline $\begin{array}{l}\text { Kyiv region, Kyiv-Sviatoshynskyi } \\
\text { district Private enterprise }\end{array}$ & Missing & + & $7.0 \pm 0.3$ \\
\hline $\begin{array}{l}\text { Kyiv region, Vasylkiv, Private } \\
\text { enterprise }\end{array}$ & Brownish-dark fruiting bodies & + & $6.3 \pm 0.3$ \\
\hline $\begin{array}{l}\text { Production agro-industrial } \\
\text { complex, Kyiv }\end{array}$ & Brownish-brown spots & + & $1.6 \pm 0.6$ \\
\hline
\end{tabular}

Examination of fruiting bodies of dicotyledonous mushrooms in mushroom farms of Vasylkiv, Kyiv-Sviatoshynsky and Makariv districts of Kyiv region and industrial mushroom enterprises of Kyiv in the period from 2011 to 2017 took 
more 740 samples, of which 87 revealed symptoms characteristic of viral diseases.

We have selected to analyze the fruiting bodies with disease symptoms. The fruiting bodies that didn `t have symptoms according to a visual assessment and electron microscopic analysis (Grogan and Bostan, 2002; Ivanova, 2019) were as control.

\section{Total and viral RNA isolation}

These methodologies were carried out the detection of total and doublestranded RNAs in Basidiomycetes (Valverde and Guttierez, 2005).

Molecular biological method of extraction total DNA, cDNA, reverse transcription of PCR, amplification, sequencing of viral cDNA, and dsRNA were performed according to the method described previously (Morris and Dodds, 1979; Melnychuk and Valverde, 2001). Biotechnological (obtaining and subcultivation of samples of mycelium in vitro using electrophoresis in agarose and polyacrylamide gels (PAGE) (Melnychuk and Valverde, 2001), determining the hydrogen index $(\mathrm{pH})$ of the nutrient medium), mycological (a measurement of growth).

\section{Statistical analysis of data}

Statistical analysis of data has been carried out with the help of statistical and other computer software.

\section{RESULTS AND DISCUSSION}

The essence, uniqueness and practicality of the method lies in the isolation from the total number of nucleic acids, which is inherent only in the virus is dsRNA. The method was first proposed and published by Morris and Dodds. Its specificity is to detect a double-stranded form of viral nucleic acid, which is also a nucleic acid of viral origin. Later, Valverde and Melnychuk improved the technique. The improved method of diagnosis and identification of RNAcontaining phytoviruses involves the following stages: $3.5 \mathrm{~g}$ of plant sample (affected areas of leaves, stems, roots, seeds, etc.) to homogenize in a buffer solution of STE $(0.1 \mathrm{M} \mathrm{NaCl}, 0.05 \mathrm{M}$ tris-HCl, $1.0 \mathrm{mM}$ EDTA, $\mathrm{pH} 7.0)$ under liquid nitrogen. (Figure 1)

After homogenization, there is a stage of phenolic isolation and purification of total nucleic acids and two cycles of cellulose fractionation, which include several stages using $16 \%$ ethanol solution. The dsRNA fraction after cellulose filtrate was transferred to STE buffer without ethanol and concentrated in two volumes of cooled $95 \%$ ethyl alcohol and 0.1 volume of $0.2 \mathrm{M}$ sodium acetate, $\mathrm{pH} 5.5$.

Insofar as the research the method of diagnosis and identification of RNAcontaining phytoviruses that methodology of isolation in the case of Basidiomycetes didn't fully ensure the purity. Noticeable, there was not sufficient concentration of nucleic acids and their double-stranded form.

Impressive data has been accumulated on the novel techniques, but the potential methodology will still remain renewed. 


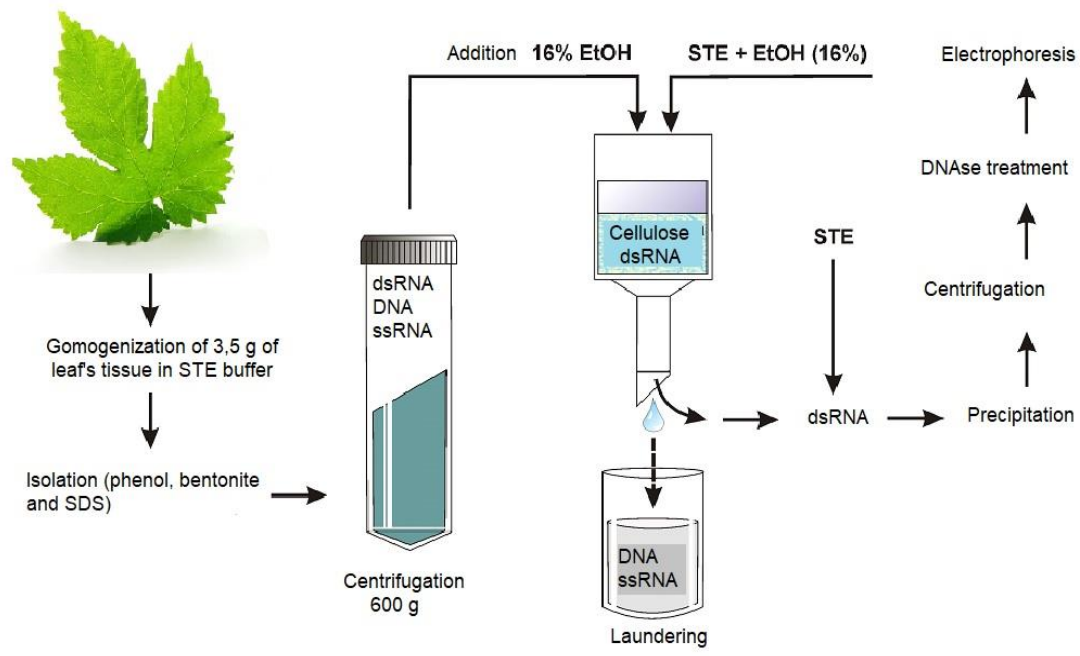

Figure 1: General scheme of isolation and chromatographic purification of double-stranded RNA

\section{Isolation of nucleic acids.}

The molecular characterizations of MVX dsRNAs were locally initiated and developed by the research. Fresh diseased fruiting bodies samples with MVX symptoms were finely grounded under liquid nitrogen in a mortar. The powder then was transferred to tubes and the protocol was followed for isolation of dsRNAs. Isolation of total nucleic acids from fruit bodies and spawn run compost was achieved via the procedures described according to the new protocol: then this powder transferred to centrifuge with $12 \mathrm{ml} 2 x$ STE buffer $\left(\mathrm{H}_{2} \mathrm{O}-500 \mathrm{ml}\right.$, $\mathrm{NaCl}-29 \mathrm{~h}$, tris $-30,5 \mathrm{~h}$, EDTA $-1,85 \mathrm{~h}), 1 \mathrm{ml}$ of $1 \%$ SDS $\left(\mathrm{H}_{2} \mathrm{O}-100 \mathrm{ml}\right.$ of SDS $-10 \mathrm{~g}$ ) and $1 \mathrm{~mL}$ of bentonite. Next step is mixing this composition on a shaker for $15 \mathrm{~min}$ until smooth. Then the addition $17 \mathrm{ml} \mathrm{STE}$-phenol $\left(\mathrm{H}_{2} \mathrm{O}-500\right.$ $\mathrm{ml}, 2$ x STE $-500 \mathrm{ml}, \mathrm{pH} 4.5$ ) plus $17 \mathrm{ml}$ of chloroform-isoamyl (24:1). It should be centrifuge for $2500 \mathrm{~g} / \mathrm{min}$ for a $20 \mathrm{~min}$. After centrifugation the aqueous phase was retrieved and again centrifugation at $8000 \mathrm{~g} / \mathrm{min}$ for 10 minutes. After that, the $1.5 \mathrm{~g}$ cellulose and $3 \mathrm{ml}$ of absolute ethanol are added to retrieving precipitate. These samples stirred for 15-20 minutes. Further, it transferred to the ice at temperature $-15^{\circ} \mathrm{C}$ for 30 minutes. The contents of the tubes were poured into a column and added buffer STE-OH (STE - $100 \mathrm{ml}$ ethanol - $174 \mathrm{ml} \mathrm{H}_{2} \mathrm{O}-$ $726 \mathrm{ml}$ ) and $20 \mathrm{ml}$ of STE buffer $-20 \mathrm{ml} .30 \mathrm{ml}$ of ethanol was added to these filtrates. The centrifugation at $8000 \mathrm{~g}$ for 30 minutes. Samples were dried on filter paper for 2 hours at a temperature of $+18-20{ }^{\circ} \mathrm{C}$. To the same tube was added 200 $\mathrm{ml}$ 10XRNA-buffer $(0.35 \%$ (w/v) Orange G, $30 \%(\mathrm{w} / \mathrm{v})$ Ficoll 400, $1 \mathrm{mM}$ EDTA). To the resulting solution applied $1 \mathrm{ml} \mathrm{MgCl}_{2}$ and was transferred to a thermostat $+37^{\circ} \mathrm{C}$ for 1 hour. 


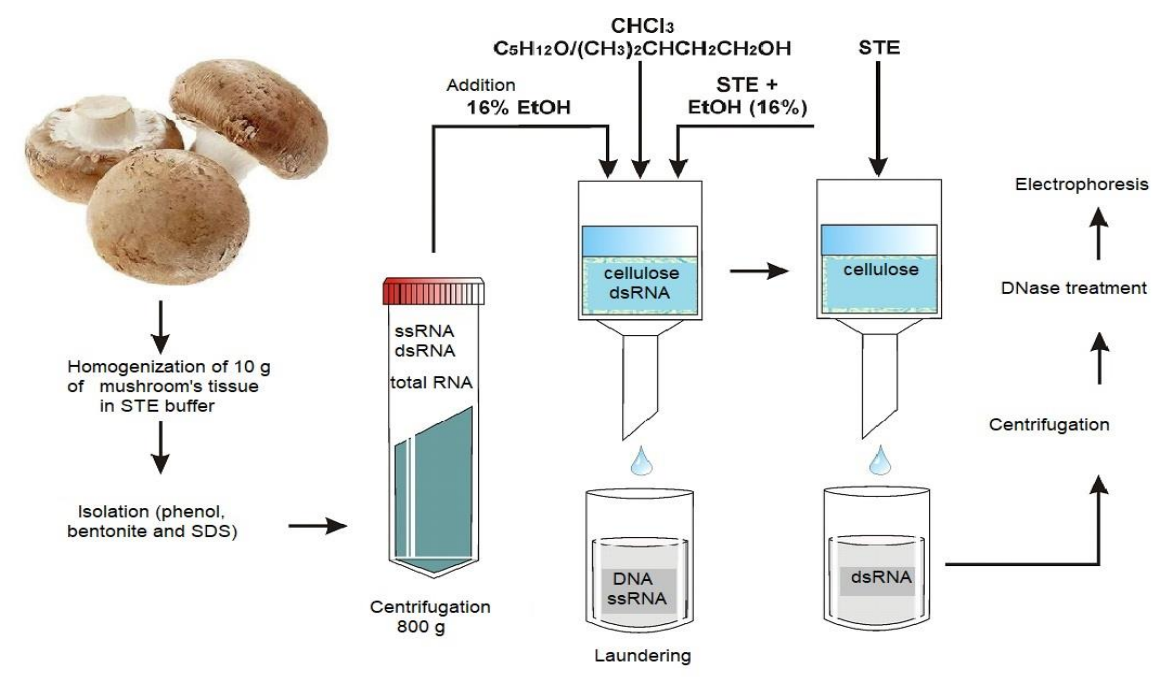

Figure 2: Scheme Advanced in the methodology of extraction total and viral nucleic acids from mushroom

In consequence of an alternative step for reducing the loss of RNA from natural abrasives by increasing the weight of samples to $10 \mathrm{~g}$, STE buffer volume $(30 \mathrm{ml})$ for initial washing, adding $50 \%$ by volume of phenol, $17 \mathrm{ml}$ of chloroform, and $2 \mathrm{ml}$ of isoamyl alcohol. Under conditions of allocation doublestranded viral RNA appears to confirm the effectiveness of the proposed method of diagnosis and identification of total and viral RNA in Basidiomycetes.

It's generally known that scientists studied the FISH method as a controversial and interesting point for our research works. A limited understanding exists of the localization and mobilization of viruses within the mycelium of A. bisporus. To this end, a non-destructive fluorescence in situ hybridization (FISH) method was developed (Coates, Eastwood, Fitzpatrick, Grogan, 2020) for in situ targeting of AbV6 and AbV16 in A. bisporus mycelium. Localization of the two viruses in MVX-infected cultures appears independent, as both viruses were found in completely discrete areas of the mycelium in differential patterns. FISH detected the low-level presence of the two viruses, AbV6 and AbV16 in a number of cultures that had tested negative for the viruses by RT-PCR. This suggests that FISH may be more sensitive at detecting viruses at low levels than molecular methods.

Simultaneously, proposing our methodology with updating techniques extraction demonstrates a powerful tool in the field of mycovirology.

Regarding molecular biological identification of fragments, dsRNA is constant for specific representatives of mycoviruses pathogen. It is a method of diagnosis and identification of RNA-containing in other stages of transport carriers (fungi, insects, nematodes, etc.) as opposed to the FISH method. The results of isolation and identification of total and mycovirus`s dsRNA in 
combination with classical methods of virus diagnostics allow studying the issue of localization and transfer of the virus in mushrooms.

Weighty use of modificated method can be used for mushroom phytosanitary control systems, quarantine, Ukrainian customs.

Our research has shown the analysis of dsRNA which isolated from mushrooms imposed the presence of viral infection. This method ensures the high quality of diagnosis and identification of RNA-containing viruses in mushrooms.

To intensify the industrial production of mushrooms on a virus-free basis and prevent the spread of mycoviruses we recommended in the early stages of growing to conduct a comprehensive diagnosis of virus mycelium. Development of test systems based on PCR will be the next step in our research.

\section{CONCLUSIONS}

Proposed own modification of this method is based on acceleration stage of cellulose chromatographic purification of nucleic acids and dsRNA fractionation. It has been proposed to conduct the first stage of low speed centrifugation at high speeds from $6000 \mathrm{~g}$ to $8000 \mathrm{~g}$. Such centrifugation is performed according to the method after the first phenolic isolation of common nucleic acids. In the future, it has been proposed to conduct only one instead of two stages of cellulose gradient for double-stranded ribonucleic acids of the studied sample. As a result of modification, a large number of studied nucleic acids are stored.

As a result of the dsRNA analyses that are isolated from the fruiting bodies of mushrooms a viral infection has been found. Based on the experiments it has been recommended to use aliquot amount $10 \mathrm{~g}$, the amount STE buffer for primary washing $30 \mathrm{ml}$, adding $50 \%$ by volume of phenol, $17 \mathrm{ml}$ of chloroform and $2 \mathrm{ml}$ isoamyl alcohol. This method provides high quality diagnostics and identification of RNA-containing viruses in mushrooms.

\section{REFERENCES}

Coates C.J., Eastwoodb, D.C., Fitzpatrickad, D. A., Grogan H. (2020) FISHing in fungi: Visualisation of mushroom virus $\mathrm{X}$ in the mycelium of Agaricus bisporus by fluorescence in situ hybridisation Journal of Microbiological Methods. V. 173, June, 105913. https://doi.org/10.1016/j.mimet.2020.105913

Elibuyuk, I., Bostan, H. (2010). Detection of a virus disease on Agaricus bisporus (white button mushroom) in Ankara, Turkey. International journal of agriculture \& biology, no.12, pp. 597-600.

Grogan, H.M., Adie, B.A., Gaze, R.H. (2003). Double-stranded RNA elements associated with the MVX disease of Agaricus bisporus. Mycol. Res, no. 107 (2), pp. $147-154$.

Grogan, H.M., Tomprefa N. (2002). Epidemiology of Virus X complex. Final Report for HDC Contract, no.39a, 30 p.

Ivanova,T.V. (2018). Biotechnology of mushrooms. V.2. Komprynt. 165 p.

Ivanova, T. V. (2019). Effects of membranotropic microfertilizers to grow the mycelium. Journal of microbiology, biotechnology and food sciences. Vol. 9 № 3, 2019., 605 609 https: doi:10.15414/jmbfs.2019/20.9.3.605-609 
Ivanova, T.V. (2015). Features of extraction of nucleic acids of viral nature from mushrooms. Scientific Bulletin of the National University of Life and Environmental Sciences of Ukraine. - 2015. - V. 214. - P. 106-111.

Ivanova, T.V. (2019). Diagnosis of mycoplasma infections in interaction with edible fungi of the species Agaricus bisporus in agroecosystems. T.V. Ivanova Collection. Science. works "Myronivskyi Visnyk». - 8., 2019. — P. 46-58.

Ivanova, T.V. (2020) Prerequisites for the action of mixed infections of basidiomycetes in closed agrobiocenoses / T.V. Ivanova // Quarantine and plant protection. № 7-9, 2020. - P. 26-28. https://doi.org/10.36495/2312-0614.2020.7-9.26-28

Klyachenko, O., Prysiazhnuk, L. (2019). Evaluation of genetic distances correlations among sugar beet genotypes (Beta vulgaris L.) //Agiculture and Forestry, -V.65 Issue 1: P. 39-48. doi: 10.17707/AgricultForest.65.1.04

Maffettone, E. (2007). Characterization of a novel virus associated with the MVX disease of Agaricus bisporus: Phd thesis for the degree of Doctor of Philosophy. $273 \mathrm{p}$.

Melnychuk, M.D., Valverde, R.A. (2001). Diagnosis and identification of RNAcontaining phytoviruses at the stages of their biosynthesis in the study of physicochemical authorities of viral double-stranded RNA. Reports of the National Academy of Sciences of Ukraine. -. - № 3. - P. 175-178.

Morris, T.J. and J.A. Dodds (1979). Isolation and analysis of double-stranded RNA from virus-infected plant and fungal tissue. Phytopathol. 69: 854-858.

Patyka V.P., Zhitkevich N.V., Ivanova T.V., Tarasyuk T.V. (2019). Morphologicalcultural and physiological-biochemical features of isolates of pathogenic bacteria of dicotyledonous mushrooms. Plant protection and quarantine № 65, 2019. - P. 60-75.

Patyka, M.V., Ivanova T.V., Tarasyuk, T.V. (2019). Functional features of trophic action of carbon sources by pathogenic bacteria of mushrooms (Agaricus bisporus). Quarantine and plant protection. № 11-12, 2019.P. 9-13. https://doi.org/10.36495/2312-0614.2019.11-12.9-13

Pereima, I. V., Ivanova, T. V. (2017). Stimulation of growth of species of the fungus of the genus Pleurotus (Fr.) P. Kumm. at a glucose nutrition. Biotechnologia Acta., 10(6), P. 45-52. doi: org/10. 15407 / biotech10.06.045.

Pidmarkova, K.A., Ivanova, T. V., Patyka, M.V. (2019) Bioconversion of organic substances of cave substrates into compost with the help of biopreparation Extracon // Bulletin of agrarian science. № 12, 2019. - P. 30-34. https://doi.org/10.31073/ agrovisnyk201912-04

Valverde, R.A., Guttierez, D.L. (2005). Transmission of a dsRNA in bell pepper and evidence that it consists of the genome of an endornavirus. Virus Genes, no. 35, pp. 399-403.

Vanina, O. Yu., Ivanova, T.V. (2019). Sucrolytic functions and molecular-biological diagnostics of pathogenic bacteria of mushroom. Collection. science. works "Myronivskyi Visnyk». - Vol. 6, 2019. — P. 25-30. 